\title{
Cortical laminar necrosis due to hypoglycaemic encephalopathy:-images in medicine
}

\author{
Chandrasekharan Rajasekharan, ${ }^{1}$ Balan Jithesh, ${ }^{2}$ Sanu Watson Renjith ${ }^{3}$
}

${ }^{1}$ Department of Internal Medicine, Medical College Hospital, Thiruvananthapuram, Kerala, India

${ }^{2}$ Department of Internal Medicine, Government Medical College, Thiruvananthapuram, Kerala, India

${ }^{3}$ Department of Internal Medicine, Government Medical College, Thiruvananthapuram, Kerala, India

\section{Correspondence to} Professor Chandrasekharan Rajasekharan, drcrajasekharan@yahoo.com

\section{DESCRIPTION}

A 74-year-old man was brought to emergency services when he was found lying unresponsive in his room. Nearest of the kin reported that his clothes were drenched with sweat and that he was a regular alcohol user who had consumed in excess the previous day. Vital signs were normal. There was decerebrate posturing of limbs with bilateral extensor plantar response. The doll's eye movement and corneal reflexes were preserved. There was no neck stiffness. Random blood sugar at admission was $34 \mathrm{mg} / \mathrm{dl}$, which was corrected with $100 \mathrm{ml} \mathrm{25 \%}$ dextrose bolus infusion which was maintained with dextrose infusion and glucagon $1 \mathrm{mg}$ intramuscular as injection. His brain CT scan was normal. The spinal tap yielded normal results. The ECG, echocardiogram, four vessels Doppler neck including the aortic arch and Electroencephalogram were normal. MRI of the brain showed hyperintense signals in both hippocampi, right insular, temporal, occipital and frontal cortex in diffusion-weighted images with diffusion restriction in apparent diffusion coefficient mapping suggestive of laminar cortical necrosis. MR angiogram was normal. He did not improve with treatment and succumbed to the illness (figures 1A, B, C and 2A, B, C).

First described in a patient with anoxic encephalopathy, ${ }^{1}$ it was found later that laminar cortical necrosis represented cytotoxic oedema affecting a particular layer of cerebral cortex neuropathologically characterised by delayed selective neuronal necrosis and is a consequence of hypoxic-ischaemic encephalopathy, hypoglycaemic encephalopathy, status epilepticus and ischaemic stroke. $^{2}$ Mechanisms of laminar cortical necrosis are not well elucidated.
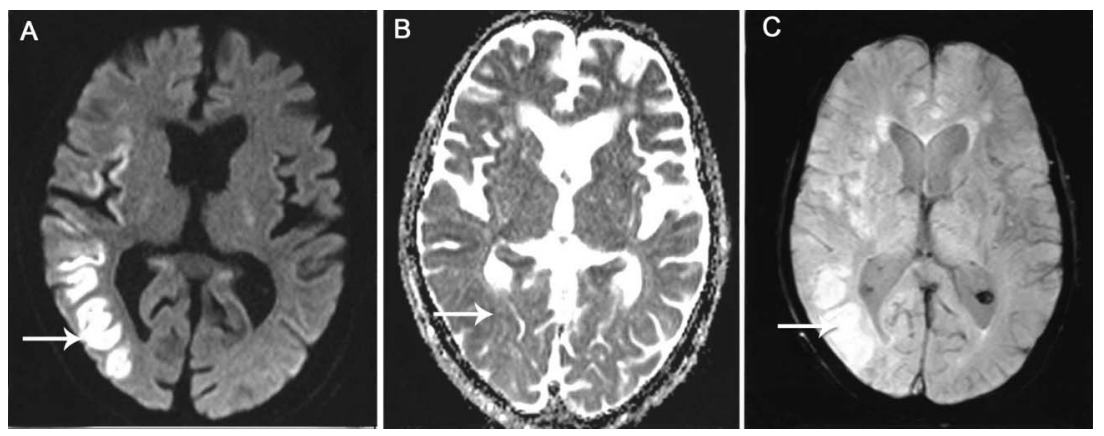

Figure 1 (A) Diffusion- weighted MRI shows linear hyperintensities in a gyral pattern in right parietal and insular cortices (white arrow). (B) MRI Apparent diffusion coefficient image showing hypo intensities in these areas suggestive of restriction of diffusion.(C) Susceptibility weighted image shows hyper intensities within the right parietal and insular cortices without blooming artifacts.
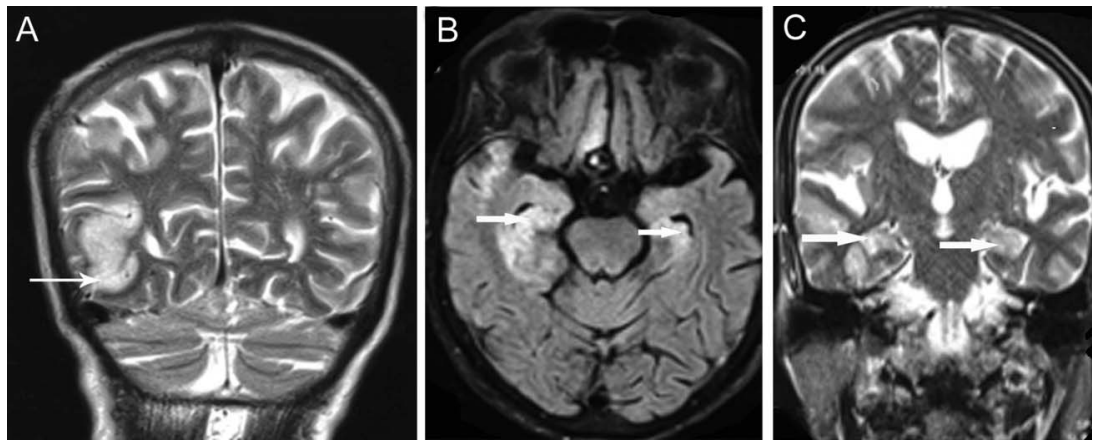

Figure 2 (A) MRI coronal T2-weighted image of brain showing hyperintense signals from medial temporal lobe (thick white arrow) of right side sparing cerebellar hemispheres. (B) MRI FLAIR images showing hyperintensities in the hippocampal region and parahippocampal gyrus right more than the left. (C) MRI brain coronal section T2-weighted images showing hyperintensities bilaterally in the hippocampal region. 


\section{Learning points}

- MRI finding of laminar cortical necrosis, even though first classically described in anoxic encephalopathy, simply represents cytotoxic oedema of varying aetiology and is a poor prognostic indicator.

- Hypoglycaemia disrupts protein synthesis in the superficial layers of the cortex, in the caudate, in the putamen and in certain cell populations of the hippocampus, whereas cerebellar and brain stem protein synthesis is relatively unaffected. ${ }^{3}$

- Cortical grey matter has six layers and of these three are most vulnerable to depletion of oxygen and glucose. Hypoglycaemic and hypoxic insult leads to death of neurons, glia, blood vessels and degradation of proteins. ${ }^{3}$

- Cerebral cortical laminar necrosis might be another clue for predicting the poor prognosis in an individual with hypoglycaemic insult. ${ }^{4}$
Competing interests None.

Patient consent Obtained.

Provenance and peer review Not commissioned; externally peer reviewed.

\section{REFERENCES}

1 Sawada H, Udaka F, Seriu N, et al. MRI demonstration of cortical laminar necrosis and delayedwhite matter injury in anoxic encephalopathy. Neuroradiology 1990;32:319-21.

2 Finelli PF. Diffusion-weighted MR in hypoglycemic coma. Neurology 2001;57:933.

3 Barkovich AJ, Ali FA, Rowley HA, et al. Imaging patterns of neonatalhypoglycemia. AJNR Am J Neuroradiol 1998;19:523-8.

4 Lee BW, Jin ES, Hwang HS, et al. A case of hypoglycemic brain injuries with cortical laminar necrosis. J Korean Med Sci 2010;25:961-5.

Copyright 2013 BMJ Publishing Group. All rights reserved. For permission to reuse any of this content visit http://group.bmj.com/group/rights-licensing/permissions.

BMJ Case Report Fellows may re-use this article for personal use and teaching without any further permission.

Become a Fellow of BMJ Case Reports today and you can:

- Submit as many cases as you like

- Enjoy fast sympathetic peer review and rapid publication of accepted articles

- Access all the published articles

- Re-use any of the published material for personal use and teaching without further permission

For information on Institutional Fellowships contact consortiasales@bmjgroup.com

Visit casereports.bmj.com for more articles like this and to become a Fellow 